\title{
SOCIAL CRITICISM IN KONSPIRASI ALAM SEMESTA NOVEL BY FIERSA BESARI
}

\author{
Hapni Nurliana H.D Hasibuan, Anwar Effendi and Margana \\ Language and Art Faculty, Yogyakarta State University, Jl. Colombo Yogyakarta No. 1, Karang \\ Malang, Caturtunggal, Kec. Depok, Kab. Sleman, DI Yogyakarta, 55281, Indonesia \\ E-mail: hapninurliana.2019@student.uny.ac.id; anwar@uny.ac.id; margana@uny.ac.id
}

\begin{abstract}
Every litterateur makes existing issues or phenomena as inspiration in making literary works. In case with novelist, they convey criticism expressly or implicitly in their novel. Besides the love story, the Konspirasi Alam Semesta novel by Fiersa Besari, the author also criticizes the social conditions that exist in Indonesia. Social criticism in the novel will be the purpose of this research. Furthermore, this research focuses on analyzing the Konspirasi Alam Semesta novel using a sociological literary approach with social criticism. The research method is qualitative research methods with reading and note-taking techniques. The purpose of the research is to describe the problem of social criticism and the form of its presentation in the novel. The research result has obtained: (1) social criticism about politics such as discrimination against families of ex- political prisoner, government policies towards those who have made the country proud, Papua's wealth and injustice in the development of remote areas, (2) moral criticism of corruption, (3) social criticism of humanity such as generalizations about a group, individual differences, violence against separatists and stigma about spinster, (4) social criticism about religion / belief about the creator. It can be concluded that the author implicitly conveyed his message and response through the Konspirasi Alam Semesta novel. It describes conditions that deviate from social conditions that must be criticized. This novel revives the people's insights about social problems that exist in Indonesia. Furthermore, the author's main topic of social criticism is political and humanitarian in Indonesia.
\end{abstract}

Key words: literature sociology; social criticism; novel; Konspirasi Alam Semesta; Fiersa Besari

\section{KRITIK SOSIAL DALAM NOVEL KONSPIRASI ALAM SEMESTA KARYA FIERSA BESARI}

\begin{abstract}
ABSTRAK. Setiap sastrawan dapat menggunakan isu atau fenomena yang ada sebagai inspirasi dalam membuat karya sastra. Sama halnya dengan novelis, mereka dapat menyampaikan kritik, baik secara tersurat maupun tersirat dalam tulisan novelnya. Novel Konspirasi Alam Semesta karya Fiersa Besari bukan hanya membahas tentang kisah cinta sepasang kekasih, penulis juga mengkritisi kondisi sosial Indonesia terkini. Kritik sosial dalam novel tersebut yang menjadi tujuan penelitian ini. Selanjutnya, penelitian ini berfokus pada analisis novel Konspirasi Alam Semesta menggunakan pendekatan sosiologi sastra dengan kritik sosial. Metode penelitian yang digunakan adalah metode penelitian kualitatif dengan teknik baca dan catat. Tujuan dari penelitian ini adalah mendeskripsikan masalah kritik sosial dan bentuk penyajiannya dalam novel. Hasil penelitian yang diperoleh: (1) kritik sosial tentang politik seperti diskriminasi terhadap keluarga mantan tahanan polisi, kebijakan pemerintah terhadap mereka yang mengharumkan nama negara, kekayaan Papua dan ketidakadilan pembangunan di daerah terpencil, (2) kritik sosial tentang moral, seperti korupsi, (3) kritik sosial kemanusiaan seperti generalisasi tentang kelompok, perbedaan individu, kekerasan terhadap separatis dan stigma tentang perawan tua, (4) kritik sosial tentang agama / kepercayaan tentang pencipta. Maka, penelitian ini dapat disimpulkan bahwa penulis menyampaikan pesan dan tanggapannya secara implisit melalui novel Konspirasi Alam Semesta. Kesimpulan ini menggambarkan kondisi yang menyimpang dari kondisi sosial yang harus dikritik. Novel ini bertujuan untuk menyadarkan masyarakat tentang permasalahan sosial yang ada di Indonesia. Lebih lanjut, pengarang lebih menaruh perhatian dan kritik sosial pada topik politik dan kemanusiaan di Indonesia.
\end{abstract}

Kata kunci: sosiologi sastra; kritik sosial; novel; Konspirasi Alam Semesta; Fiersa Besari

\section{INTRODUCTION}

Literature is an expression of the author's experience, meaning that literature cannot be separated from the life experience of the poet, author or writer. Every literary genre, be it prose, poetry, or drama, exists as a medium for various literary experiences to readers. Every type of literature is always present as a system of cultural symbols which is the result of literary intellectuals in responding to various phenomena that are present around them. This is in line with the opinion (Wicaksono, 2013:
3) which states that literature is born as a result of the basic human impulse to express himself, has an interest in human and human problems, has an interest in reality that lasts throughout the ages.

Literary work as a portrait of people's life can be enjoyed, understood and utilized by the community. A literary work is created because of the author's experience in the form of an interesting event or problem so that ideas and imagination are expressed in written form. This includes literary works in the form of fiction present a picture of life and life itself is a social reality (Wicaksono, 2013: 1). 
Literary works are created in the midst of society as a result of the author's imagination and reflection on social phenomena around him. Literary study using a sociological literary approach then places literature as a depiction of a social reality. However, literature has a completely strong relationship with social reality. It becomes a big question in several literary studies. The existence of such literature makes literature to be positioned as a document that serves to make an inventory of a number of events in society (Jabrohim, 2001: 164).

In connection with this explanation, (Wellek et al., 1993: 122) states the novel can describe the setting in detail so that it can provide a clearer, more concrete, and definite picture. The novel is a world on a larger and more complex scale, covering various life experiences that are seen as actual, but all of which are intertwined. Novels are realistic, novels develop from non-fiction narrative forms.

Novel is one of the literary works created by its author with the hope of being enjoyed, understood, pondered, and utilized by readers. A novel usually tells about human life in interacting with the environment and others. Novels are imaginative works that tell the whole side of the problems in the life of a person or several characters (Kosasih, 2012:60). The subjectivity of individual authors influences the work they write. In short, the biographical element of the author will determine the style of the work he produces.

Literature does not simply record the facts that exist in society. Moreover, it also gave a response to the social reality he faced. One form of the author's response to the social conditions of society is manifested in literary works. These responses include social criticism in literary works. The author voices social criticism of the reality that occurs. The author became the community spokesman. $\mathrm{He}$ raised public complaints and hopes. This is related to social realities that are not in accordance with human expectations. The mismatch of reality tends to lead to dissatisfaction and the sense of dissatisfaction has led to social criticism that has been raised through various media (Kurniawan, 2011: 2).

Hence, social criticism is a form of communication in society that aims or functions as a control over the running of a social system or social process. Social criticism is an important part of maintaining social systems. Various social and individual actions that deviate morally and socially in society can be prevented by functioning social criticism. In other words, social criticism in this case serves as a reference in improving social values that exist in society. Social criticism must be carried out based on prevailing norms and rules (Abar, 1997: 44).
Sociology of literature is essentially an interdisciplinary between sociology and literature, which both include humans as the object in society (Ratna, 2009: 11). However, the essence of sociology and literature are different. Sociology is a categorical objective science confining itself to what is happening today, not what should happen. On the other hand, literature is evaluative, subjective, and imaginative.

Doing the literature research is expected to find the ways or concrete actions that increase the moral formation of a cultured younger generation so that they can create knowledgeable, moral, and highly cultured human s related to the description above. In addition, literary works can learn about the nature of life and life, even the life of the author himself, as it is said that literature is a means of conveying life, even almost all aspects of people's life are implied and even expressed in a literary work. This study aims to examine what social problems are criticized in the universe conspiracy novel and what forms of criticism are conveyed.

Many literary works contain ideas of resistance aimed at leaders, governments, and social realities that are seen as incompatible with the expectations and interests of society. This means that in the imaginative beauty of literary works there is a power that can be used to convey criticism. It is not uncommon for criticisms to be delivered in the form of solutions to problems that occur in society.

There are some previous studies about the social criticism in literary work especially novel. Delivering social criticism for literary works is meaningful as a literary way of channeling the aspirations of society. For literature, conveying social criticism is one way to position literature as a medium for releasing anxiety, concern, and even public anger. Social criticism is the author's response to the phenomenon of the problems that exist around him. Hence, it can be said that an author cannot be separated from the socio-cultural influence of his community (Dewi \& Balawa, 2017: 1; Imam, 2017: 128; Intan, 2018: 208; Nisak \& Anggraini, 2020: 147; Pangaribuan et al., 2019: 2 ; Satrio et al., 2013: 3).Based on the explanation, the aspect of the study that will be analyzed is social criticism, namely the assumption that literary works are a reflection of society. This means that literature is the work of an author who lives in society and describes some problems and events. The social problems in society can be reduced or even overcome in various ways, including by expressing criticism. As we know, the social criticism is used as the medium for criticism of social conditions takes various forms. One of the various forms is novel. 
Konspirasi Alam Semesta novel by Fiersa Besari raised some issues that contains the irony of life. The author aims to make the readers realize the importance of a life struggle. Moreover, the author wrote the story that combined with the flashback techniques. Various problems that arise in this novel are social criticism types which can be examined for its causes. This novel contains the problems of injustice, negative stigma, irony of natural wealth and generalizations as social criticism. Thus, this novel becomes the choices to analyzed in social criticism terms. Therefore, this study will examine the social problems that arise in the Konspirasi Alam Semesta novel as social criticism research material.

Based on the background of the problem at above, the research question of this research is: (1) What social criticisms are contained in Konspirasi Alam Semesta novel which are reflected in social problems? (2) How did the author criticize the social problems through the Konspirasi Alam Semesta novel?

\section{METHOD}

The research used qualitative method. (Bogdan \& Biklen (1982: 27) argued that the qualitative method is a research method that is natural and produce descriptive data in the form of written or spoken words, from people, behavior, or other observable data. The object of research on the novel Konspirasi Alam Semesta by Fiersa Besari which was published in 2017 with a total of 235 pages.

The data used are in the form of quotations of words, phrases, clauses, sentences and paragraphs that are relevant to the formulation of the problem. The data collection techniques used were reading techniques and note taking techniques. The reading technique is used to identify the hierarchy of social criticism theory studied in the Kospirasi Alam Semesta novel, which is supported by reading journals related to this research. The note-taking technique is a technique of capturing data by recording the results of listening to the data. Notetaking activities are carried out as a continuation of reading techniques. Both of these techniques are used to record social criticism description data in the novel. The recording process is accompanied by a selection or classification of data.

Meanwhile, the data analysis technique used is descriptive qualitative with the following stages: (1) reading, (2) recording data relevant to the problem formulation, (3) classifying data according to the formulation of the problem, (4) presenting and interpreting the data, (5) concluding or makng inferences, activities to interpret data based on the context.

The validity test in this study is semantic validity or content validity. Semantic validity is used to measure the level of sensitivity of a technique to symbolic meanings that are relevant to a particular context. Reliability test used in this research is interrater and intrarater, Interrater: peers, and repeated observations so that the data obtained is constant.

\section{RESULTS AND DISCUSSION}

The emergence of a literary work cannot be separated from the socio-cultural situation and conditions. According to Laurenson \& Swingewood (1974: 13) literary works are a mirror of society. Thus, literary works cannot be separated from the social conditions of a society. In addition, (Purwati et al., 2018: 292) mentions that literature is born in society as an author's imagination that reflects the social phenomena.

Furthermore, one of Fiersa Besari's works entitled Konspirasi Alam Semesta is considered capable of reflecting the socio-cultural context. It is related to the situation that occurs in the community. This novel is thought to have emerged as a response to Indonesia's social conditions which are riddled with various problems. The various relationship between social conditions and the problems was raised in the novel. This novel tries to raise the reality that occurs in society.

\section{The Stigma on the Families of Ex Political Prisoners}

The head of the family, the father of the figure Juang, is a former political prisoner. The views and treatment of the community, such as negative stigma and discrimination, can be seen from these quotes:

"Ia masih mampu merekam jelas mimik salah satu guru SMP-nya yang berang, sewaktu ia mengacungkan jari tengah sehabis guru itu memberikan pernyataan bahwa ia berasal dari keluarga ekstapol, yang iya mengerti adalah: hampir semua tetangga membenci keluarganya hanya karena sematan "gelar" tersebut" (Besari, 2017: 3).

"He is still able to clearly record the angry expression of one of his junior high school teachers, when he held up the middle finger after the teacher gave a statement that he came from an ex-political prisoner family, what he does understand is: almost all neighbors hate his family just because of the title" (Besari, 2017: 3)." 
This quote illustrates the stigma of society towards ex-political prisoner families. Even a teacher discriminates against the child of an ex-political prisoner. The teacher should have set a good example, it is feared that it will have a negative impact on their students. The quotes below are examples of insults from friends fighting against him:

"Anak eks tapol! Musuh Negara! pengkhianat! hinaan-hinaan itu biasanya berujung dengan perkelahian" (Besari, 2017: 16).

"The son of a political prisoner! Enemy of the Country! traitor! the insults usually ended in a fight" (Besari, 2017: 16).

Juang has gotten ridicule and insults since he was a child, young children of the same age who do not know anything about an ex-political prisoner

oners continue to insult, it may be a negative impact from the teacher's statement or maybe their parents have led their minds to commit the insult. As adults, they should not set a bad example for their students.

"Kulih bangunan menjadi pilihan Bapak untuk menyambung hidup. Punya tanda ETP di KTP-nya mengakibatkan ia tak mampu bebas bergerak" (Besari, 2017: 104).

"Construction workers are your choice to make a living. Having an ETP sign on his KTP makes him unable to move freely" (Besari, 2017: 104).

In this novel, social criticism about ex-political prisoners in seeking work, usually extapol only works hard in the field. Juang's father initially asked for help from the fighting mother in finding work but the stigma of society and discrimination made it difficult for him to get a job coupled with the expolitical prisoner mark. Therefore, Juang's father chose to become a building kulih to survive. There are also two quotes that the researchers found from the conspiracy novel universe, the author presents a story that criticizes the family of ex-political prisoners who are also exiled from work. "Pihak $S D$ memecat Ibu, hanya karena suami Ibu seorang eks tapol" (Besari, 2017: 108).

"The elementary school stakeholder fired my mother, only because your husband was a former political prisoner" (Besari, 2017: 108).

"Para orangtua tidak mau lagi memakai jasa Ibu mengajar les untuk anak-anak mereka". (Besari, 2017: 110).

"Parents no longer want to use the services of mothers to teach lessons for their children" (Besari, 2017: 110).
The two quotes above present the problem of the wife of a political prisoner who was expelled from the workplace and this news spread so that all parents of students did not want to use the services of a mother to teach their child tutoring. In fact, the sins and derivative punishments given to ex-political prisoners by the New Order government have exceeded the crimes against humanity committed by regimes in other countries. However, there is a mindset that has not changed, a system that works in the heads of individual humans.

The number of political prisoners who survive will continue to decrease over time. The struggle of the ex-political prisoners to restore what is stated in Pancasila as "social justice for all Indonesian people" is not continued, so the mindset of hatred will never end.

There should be an official statement from the government regarding the expiration of the expolitical prisoner, thereby, it should be eliminating the negative public perception to the ex-political prisoner and the family.

\section{The Tribute/Awards}

"Dia mau angkat berita soal Shinta Aksara, seorang sinden yang pernah mengharumkan nama bangsa di mancanegara, tapi seakan dilupakan negerinya sendiri. Bahkan sewaktu sinden tersebut meninggal, enggak pernah ada perhatian tertentu dari Negara" (Besari, 2017: 5).

"He wants to raise the news about Shinta Aksara, a sinden who has raised the name of the nation abroad, but seems to have forgotten her own country. Even when the sinden died, there was never any particular attention from the State" (Besari, 2017: 5).

Social criticism regarding the State's treatment of the people that have given the best for the state but are forgotten. It disappointed the families. In this story, it told that state did not tribute to the mother while she passed away. This social criticism is supported in a quote, as follows:

"Gadis itu tidak mempermasalahkan kucuran dana, atau sematan gelar yang tak kunjung didapatkan sang ibu: ia hanya mengeluhkan sang ibu yang terkesan dilupakan oleh bangsanya sendiri" (Besari, 2017:8).

"The girl doesn't mind the disbursement of funds, or the pinning of the title that the mother never gets: she only complains about her mother who seems to have been forgotten by her own people" (Besari, 2017: 8). 
It is clear from the above that social criticism of the hero who has made the name of the nation proud in the world. The good state is never forgot the struggle of hero. Therefore, the government should be more sensitive to people who have made Indonesia proud.

\section{The Different of Social Background}

"Kini aku paham perbedaan menjadikan kita kaya. Dan Cuma orang bodoh yang tak bisa menerima perbedaan, atau setidaknya jalan beriringan." (Besari, 2017:3).

"Now I understand that the difference makes us rich. And it's just a fool who can't accept differences, or at least go hand in hand" (Besari, 2017: 3).

The social criticism above is aimed at ignorant people who sometimes cannot accept differences, even reluctant to go hand in hand. In spite of the diversity makes the diverse and various society.

Therefore, as Indonesia people, we have to accept diversity. Our country has more than 264 million inhabitants, 17,504 islands, 1340 tribes, and three times divisions. Admitting the diversity will progress the nation and country rapidly. In line with Indonesia motto "Bhinneka Tunggal Ika" means the unity in diversity.

\section{The Belief in God}

"Berada di tengah laut dengan perahu mungil di antara badai membuatku ingat Tuhan. Manusia itu aneh. Di masa tersulit, bahkan seorang yang tidak percaya alan eksistensi Sang Pencipta pun akan mendadak percaya" (Besari, 2017: 61).

"Being in the middle of the sea in a tiny boat in a storm made me remember God. Humans are strange. In the most difficult times, even someone who does not believe in the existence of a Creator will suddenly believe" (Besari, 2017: 61).

The belief in creator or god, the author presents the problems when humans are faced with death or a state of urgency, such as preparation for exams or student hearings, reporting of performance results for employees etc.

The problem makes humans spontaneously remember God. We should remember God whenever and wherever, because we did not know about the fortune, mate or death. As his servant is simply preparing to face these three. In line with, religion seems to be a powerful factor in legitimizing an action or interest (Kurniawan, 2011: 12).

\section{Rejection of Generalizations}

"Biarpun sempat kenak palak di pelabuhan, aku tahu tidak semua orang Papua jahat. Sama seperti tidak semua orang di Bandung sana ramah. Aku merasa kasihan sama orang-orang yang selalu menggeneralisasi segalanya" (Besari, 2017: 3).

"Even though I got bad at the port, I know that not all Papuans are bad. Just like not everyone in Bandung is friendly. I feel sorry for people who always generalize everything" (Besari, 2017: 3).

The author critics the people who often rationalize other people based on their origin. It concerned for the community habit, which often describes people from their ethnic origin or region.

They often think that certain tribes have the same character. Hence, this view cannot be considered correct, because every human being is unique and different. This novel shows that an assessment of a person's personality cannot be based solely on regional or ethnic origin alone. Generalization of human groups from certain areas is not to see their personalities. Personality is included in the private realm that describes the uniqueness of the individual with all its uniqueness.

The common habit for the generalizations probably does not affect anything. However, the generalization indirectly triggers the horizontal conflict for Indonesia people. The ethnicities and cultures are affected. The spirit of unity will be eroded by the appearance of regional bonds. Accordingly, this generalization viewpoint must be changed immediately considering to diversity human being.

\section{The Irony of Nature}

"Di Papua, semua terasa seperti musim panas ceria yang menyembunykan sekelumit derita masyarakatnya. Mereka yang terus dikeruk hasil alamnya, iyalah mereka yang sama yang sulit mengecap pendidikan dan pembangunan" (Besari, 2017: 3).

"In Papua, everything feels like a happy summer, hiding a bit of the suffering of the people. Those who continue to be extracted from their natural products are the same people who find it difficult to get education and development" (Besari, 2017: 3).

The irony of the nature actually happened in Papua. Whereas Papua has the natural resources: oil, copper, and gold. Supposedly, the abundant natural resources become the asset for the people in Papua. 
In fact, the Papuan people lives below the eligibility line. In education or the capital development of the Papua island itself.

The abundant natural resources do not make the Papuan people live sufficient. It caused the irony in Papua nature. The Papua people only get suffering with the land being dredged continuously by the irresponsible authority.

This criticism is aimed to make the government to stop the suffering of the Papuan people. In addition, the author's critic shows the anger at the government's ignorance. The author emphatically states the government's fault for neglecting to pay attention to the conditions of the Papuan people. The author regrets that Papua's natural resources should be sufficient to enable Papuan people receiving the proper education and development.

\section{Treatment of Separatists}

"Sejak itu perburuan terhadap para separatis digiatkan secara membabi buta. Banyak sahabat dan saudaranya lenyap secara misterius atau bahkan meninggal dan dibiarkan begitu saja di jalanan. Semua atas nama "mempertahankan kesatuan." Pace Johan tidak pernah paham mengapa sebuah protes dan keinginan harus ditindak represif seolah tidak ada jalan damai berbentuk musyawarah. Aku pun tidak pernah paham" (Besari, 2017: 90).

"Since then the hunt for separatists has been blindly intensified. Many friends and relatives mysteriously disappeared or even died and were left on the streets. All in the name of "maintaining unity." Pace Johan never understood why a protest and desire should be repressed as if there was no peaceful way in the form of deliberation. I never understood" (Besari, 2017: 90).

The existence of separatists is often seen as a threat to the state. Therefore, the separatists got the inhuman resistance. In addition, the differences of two groups thought or command could threaten the sovereignty of the country. It caused the attack between them.

Hence, the word "unity" becomes impossible to materialize. The quote above shows the author rejects the action taken by the state. Indonesia has the Pancasila ideology with the 4th principle which reads "Fair and civilized deliberation," the precept should be a solution in dealing with separatists.

The repressive actions are inhumane in society. In addition, it also triggers the separatists to be even more aggressive. This action affects the rebels and the civil society. To solve this problem, the government should establish open communication by diplomacy to negotiate for the society.

\section{Development Injustice}

"Aku berharap Indonesia yang dapat berlaku adil pada masyarakatnya yang jauh dari jangkauan Ibu Kota sana" (Besari, 2017: 3).

"I hope Indonesia can do justice to its people who are far from the reach of the capital there" (Besari, 2017: 3)

One of Indonesia's problems is unequal development. In line with the irony of nature before, it shows that the development in Papua island is retarded. It means that the development in Indonesia gains the partial. This development can be said the government merely focused to develop the Java island, especially the capital city, Jakarta.

The partial development resulting in the problem enhancement, from the social to economic inequality. It affects the gap in society. As it is known that Indonesia has 17,504 islands, from Sabang to Merauke. Therefore, every island should receive the same treatment and development for the realization of the principle of "Social justice for all Indonesian people.

\section{The negative Stigma of Spinster}

The gender equality issue is the idea of equality in obtaining education, expressing love, gaining freedom of action, pouring out thoughts and emotions, obtaining equality itself, and getting love (Sachmadi et al., 2014:150).

This novel has social criticism for the spinster. Indonesia people has the negative stigma for the woman that did not marry yet.

"Era delapan puluhan dan tinggal di pedesaan membuat ibu mau tidak mau memaklumi stigma yang mengatakan perempuan lajang di atas dua puluh tahun sama dengan perawan tua. Tetapi ibu tidak peduli" (Besari, 2017: 3).

"The eighties era and living in rural areas made mothers inevitably tolerate the stigma that says single women over twenty years old are spinster. But mom doesn't care" (Besari, 2017: 3)..

Old virgins are often viewed as a shame. Women experience discrimination against the age of marriage. age is often a benchmark to determine a person's readiness to marry. as in the quote, which considers the age above twenty if not married is considered an old maid. This assumption is closely related to the strength of ancient traditions in Indonesia. 
However, the character of the mother in the story shows indifference. It reflects social criticism of the rejection of conservative attitudes in society. He did not cause problems with the label that society had given him. This shows that he wants to change customs which tend to discriminate against women.

\section{Position for Making Money}

"Mereka, teman-teman SD-ku yang sok borju itu, dungu Bu. Apa yang buruk dari berjualan nasi goreng? Apakag lebih baik menjadi ayah-ayah mereka yang pejabat, lalu memakai jabatannya untuk mencuri uang rakyat?" (Besari, 2017: 3).

"They, my bourgeois pretentious elementary school friends, you idiot Mom. What's so bad about selling fried rice? Is it better to be their official fathers and then use their positions to steal people's money?" (Besari, 2017:3).

There is no secret that the government can live a luxurious lifestyle with the money that the people sweat. Indonesia is too familiar with the habit of corruption. They do not realize that they are just a community service living off people's wages. They should put themselves into service with the people who sit as bosses. However, they do not know themselves about the bourgeois lifestyle.

Criticisms conveyed by the author in the form of satire are harsh enough to remind officials of his mistakes. Moreover, their habit is passed on to their children. However, the official's family is no longer aware that the wealth they get is people's money. This shows the low morale of officials so that they are increasingly accustomed to committing corruption.

The problem of political penetration and government administration with its various appearances is only a tool to optimize the achievement of economic targets. Meanwhile, political policy and government administration are more than a tactic which in practice can change according to situations and conditions; whereas economic interests - that is, achieving the greatest economic benefits for the parent country - is an almost eternal strategy (Zakaria, 2011: 104).

\section{CONCLUSION}

Writing literary works with spices of social criticism for a writer is not just criticizing other parties. The author, too, in his own way provides alternative solutions to the problems he is talking about. Therefore, literary works can also be considered as a form of public enlightenment. This form of enlightenment is usually in line with the author's background and contributes to the coloring of the literary works he writes.
Based on the results of the research and discussion that has been carried out on the study of social criticism in the Konspirasi Alam Semesta by Fiersa Besari, the researchers concluded that this novel has a variety of social problems, including: (1) social criticism of politics such as discrimination against the families of ex-political prisoners, government policies towards those who have made the name of the country proud, Papua's wealth and injustice in the development of remote areas, (2) moral criticism of official corruption (3) social criticism of humanity such as generalization against a group, individual differences, violence against separatists and the stigma of spinster (4) social criticism about religion, beliefs about the creator.

The author pays more attention to political and humanitarian issues. Hence, the author implicitly conveyed his message and response through the Konspirasi Alam Semesta novel. It describes a condition deviates from the social condition that should be criticized. Therefore, this novel can also open people's insights about social problems in Indonesia.

\section{REFERENCES}

Abar, A. Z. (1997). Kritik Sosial, Pers Dan Politik Indonesia. Unisia, 17, (32), 44-51.

Besari, F. (2017). Konspirasi Alam Semesta. Jakarta: Pt Mediakita.

Bogdan, R. C., \& Biklen, S. K. (1982). Qualitative Research For Education. Boston: Allyn And Bacon, Inc.

Dewi, W. O. S., \& Balawa, L. O. (2017). Kritik Sosial Dalam Novel Surat Cinta Untuk Kisha Karya Bintang Berkisah Wa. Jurnal Bastra, 1, (4), 1-13.

Imam, A. (2017). Kritik Sosial Dalam Novel O Karya Eka Kurniawan: Kajian Sosiologi Sastra. Humanis, 9, (2), 127-134.

Intan, T. (2018). Narator Sebagai Penyampai Kritik Sosial Dalam Novel Moha Le Fou Moha Le Sage Karya Tahar Ben Jelloun. Jurnal Ilmu Budaya, 6, (2), 207-220.

Jabrohim. (2001). Metodologi Penelitian Sastra. Yogyakarta: Hanindita Graha Widya.

Kosasih. (2012). Dasar-Dasar Keterampilan Bersastra. Bandung: Yrama Widya.

Kurniawan, M. A. (2011). Kritik Sosial Dalam Novel Menunggu Matahari Melbourne Karya Remy Sylado: Tinjauan Sosiologi Sastra. Jurnal Bahastra, 26, (1). 
Laurenson, D., \& Swingewood, A. (1974). The Sociology Od Literature. London: Granada Publishing Limited.

Nisak, K., \& Anggraini, P. (2020). Kritik Sosial Dalam Novel "Anak-Anak Tukang” Karya Baby Ahnan. Alinea: Jurnal Bahasa, Sastra, Dan Pengajaran, 9, (2), 146-154. Https:// Doi.Org/10.35194/Alinea.V9i2.990

Pangaribuan, N. N., Br Ginting, N. V., Br Purba, R. W., Aritonang, P., \& Annisa, A. (2019). Kritik Sosial Pada Novel "Dilan: Dia Adalah Dilanku Tahun 1990" Karya Pidi Baiq. Jurnal Genre (Bahasa, Sastra, Dan Pembelajarannya), 1, (1), 1-8. Https://Doi. Org/10.26555/Jg.V1i1.1051

Purwati, Rosdiani, R., Lestari, R. D., \& Firmansyah, D. (2018). Menganalisis Gaya Bahasa Metafora Dalam Novel "Laskar Pelangi" Karya Andrea Hirata. Parole (Jurnal Pendidikan Bahasa Dan Sastra Indonesia), 1, (3), 291-302.
Ratna, N. K. (2009). Teori, Metode, Dan Teknik Penelitian Sastra. Yogyakarta: Pustaka Pelajar.

Sachmadi, I. F., Damono, S. D., \& Widiawati, H. (2014). Pengungkapan Gagasan-Gagasan Tentang Ketidakadilan Gender Dalam Novel Geni Jora. Sosiohumaniora, 16, (2), 149-155. Https://Doi.Org/10.24198/Sosiohumaniora. V16i2.5727

Satrio, B. S., Doyin, M., \& Suseno. (2013). Kritik Sosial Dan Hegemoni Kumpulan Cerpen Emak Ingin Naik Haji Karya Asma Nadia. Jurnal Sastra Indonesia, 2, (1), 1-10.

Wellek, R., \& Warren,A. (1993). Teori Kesusastraan, Terjemahan Melani Budianta. Jakarta: Gramedia.

Wicaksono, A. (2013). Pengkajian Prosa Fiksi. Bandung: Garudhawaca.

Zakaria, M. M. (2011). Dinamika Sosial Ekonomi Priangan Abad Ke-19. Jurnal Sosiohumaniora, 13, (1), 10-14. 